\title{
UPAYA MENINGKATKAN HASIL BELAJAR DAN KEAKTIFAN BELAJAR MATEMATIKA MELALUI PENDEKATAN KONTEKSTUAL TEKNIK BERMAIN MENGGUNAKAN KARTU "BILANGAN KUBIK-AKAR PANGKAT TIGA" SISWA KELAS VI SD NEGERI 02 SIDOMULYO TAHUN PELAJARAN 2012/2013 \\ Casto Nuredi
}

(Guru SDN 02 Sidomulyo, Kec. Lebakbarang, Pekalongan)

\begin{abstract}
Abstrak :playing by learning bermain untuk belajar. Manusia secara kodrati dikatakan sebagai Homo luden makhluk bermain.Dan memang sehatinya kecenderungan manusia adalah untuk bermain. Kami mencoba untuk mengadakan penelitian tindakan kelas dengan menggunakan cara bermain kartu playing card yaitu kartu edukatif yang didesain sebagai kartu bilangan. Permainan ini menerapkan pembelajaran konstektual sebagai bagian dari Quantum math learning (QML).

Penelitian ini bertujuan untuk menentukan besaran peningkatan hasil belajar dan keaktifan belajar peserta didik kelas VI SD Negeri 02 Sidomulyo, kec. Lebakbarang, Kab. Pekalongan pada kompetensi dasar akar pangkat tiga suatu bilangan kubik yang telah mendapat perlakuan pendekatan konstektual learning berorientasi Quantum Math Learning dengan teknik bermain.

Skenario pembelajaran dimulai dari konteks kehidupan nyata (daily life) peserta didik yang gemar bermaian. Bermain ini digunakan sebagai sarana pembelajaran. Dengan cara bermain diketahui hasil penelitian bahwa ini dapat meningkatkan minat peserta didik Dalam pembelajaran kompetensi dasar akar pangkat tiga suatu bilangan kubik dan dari hasil tes diperoleh data bahwa nilai rata-rata peserta didik mengalami peningkatan pada kondisi sebelum tindakan yaitu 61,1 persen menjadi 76,8 persen pada siklus I dan 86,6 persen pada siklus II. Hal ini menunjukkan peningkatan yang cukup besar yaitu 15,8 persen pada siklus I dan 25,5 persen pada siklus II. Setelah perbaikan tindakan pada siklus II terjadi peningkatan dari siklus I sebesar 9,7 persen. Nilai tertinggi mengalami peningkatan dari 8 pada siklus I menjadi 10 pada Siklus II.
\end{abstract}

Kata kunci :Pendekatan kontekstual, teknik bermain, kartu kubik, keaktifan belajar 


\section{PENDAHULUAN}

Matematika merupakan ilmu yang universal yang mendasari perkembangan tehnologi modern.Matematika sebagai induk ilmu pengetahuan memiliki peran penting dalam berbagai disiplin dan memanukan daya piker manusia. Perkembangan pesat di bidang tehnologi informasi dan komunikasi dewasa ini dilandasi oleh perkembangan matematika. Untuk menguasai tehnologi dimasa depan diperlukan penguasaan matematika secara komprehensif sejak dini. Agar peserta didik mampu menghadapi perubahan keadaan di dunia yang senantiasa berubah kearah perkembangan yang tiada henti. Melalui latihan dan pembiasaan bertindak atas dasar pemikiran secara logis, analitis, sistematis, kritis, kreatif serta kerjasama diharapkan peserta didik akan tetap survive dalam menghadapi perubahan dan kompetisi dalam dunia global dimasa mendatang. Kompetensi tersebut diperlukan agar peserta didik dapat memiliki kemampuan memperoleh, mengelola dan memanfaatkan informasi untuk bertahan hidup pada keadaan yang selalu berubah, tidak pasti dan kompetitif.

Realita ini merupakan tagihan yang sangat tinggi yang tidak mungkin bisa dicapai hanya melalui hafalan, dril, latihan soal, mengerjakan soal dalam LKS yang bersifat rutinitas serta proses pembelajaran yang apa adanya..Pelaksanaan pembelajaran matematika di SD Negeri 02 Sidomulyo sebagai SD Inti sudah menerapkan PAKEM (Pembelajaran-Aktif-Kreatif-Efektif dan Menyenangkan). Namun sebagian pendidik diantara kami masih sering melakukan kekeliruan ketika menanamkan, menerapkan konsep serta membina keterampilan matematika pada peserta didik. Hal tersebut terjadi karena sebagian pendidik mempunyai basis pendidikan yang belum sesuai yaitu dari SMU, SMK, PGMI sehingga kompetensi pedagogiknya masih dibawah standar nasional pendidikan. Konsekuensi kompetensi mereka pada penguasaan materi, penerapan metode dan pendekatan pembelajaran, penguasaan media pembelajaran yang relevan dan inovatif, juga pemilihan system dan alat evaluasi belum sesuai dengan tuntutan KTSP. Hal ini 
berimbas pada aktifitas peserta didik kurang optimal dan hasil belajar kelas VI pada kompetensi dasar "menentukan akar pangkat tiga suatu bilangan kubik di bawah KKM : 70".

Menurut Suherman (2008:1) pembelajaran matematika dengan pendekatan konstektual akan mengubah kondisi diatas, yaitu dengan membuat skenario pembelajaran di mulai dari konsteks kehidupan nyata peserta didik (daily life) selanjutnya pendidik memfasilitasi peserta didik untuk mengangkat konteks kehidupan nyata itu ke dalam konsep matematika, dengan melalui tanya jawab, pemodelan, diskusi, inkuiri dan penilaian yang sebenarnya sehingga peserta didik dapat mengkonstruksi konsep tersebut dalam pikirannya. Pembelajaran matematika konstekstual mengajarkan kepada peserta didik dengan mempresentasikan masalah dan meng'encourage' peserta didik untuk menemukan cara mereka sendiri dalam menyelesaikan permasalahan.

Untuk meningkatkan hasil belajar dan lebih memotivasi peserta didik dalam belajar matematika, maka peneliti mencoba memberikan solusi pembelajaran yang menyenangkan yaitu permainan kartu Domino model bilangan kubik dan akar pangkat tiganya. Sebagai turunan dari pendekatan Quantum Math Learning (QML). Menurut Matrisoni (2008:1) QML adalah sebuah pendekatan belajar Matematika model quantum yang mempromosikan citra matematika sebagai ilmu yang menyenangkan, mudah, dan menantang untuk di pelajari. Menurut De Porter (dalam matrisoni 2008:1), Quantum diartikan sebagai interaksi yang mengubah (mengorkestrasi) energi menjadi cahaya. Interaksi mencakup unsur-unsur untuk belajar efektif yang mempengaruhi kesuksesan belajar. Interaksi ini menggugah kemampuan dan bakat alamiah peserta didik, yang diharapkan bermanfaat bagi mereka sendiri dan bagi orang lain. Menurut De Porter (dalam Saryono, 2008) strategi pembelajaran yang dapat ditempuh dalam pembelajaran berorientasi QML adalah sebagai berikut :

a) Menumbuhkan motivasi belajar, misalnya melalui AMBAK (Apa Manfaatnya Bagiku), 
b) Menumbuhkan rasa percaya diri

c) Menghilangkan penyebab gangguan belajar

d) Menciptakan suasana yang nyaman dan santai.

e) Meyakinkan bahwa keahlian memerlukan latihan dan pengulangan.

f) Mengenali gaya belajar yang sangat disukai peserta didik (dengan visual/melihat, auditorial/mendengar, atau dengan kinestetik/bekerja).

g) Memanfaatkan setiap waktu tanpa tekanan.

h) Ketika akhirnya tercapai tujuannya dirayakan, dan

i) Menggunakan musik yang lembut, yang disukai peserta didik.

Menurut De Porter (dalam Sudrajat 2008), Quantum Math Learning merupakan metode pengajaran yang menggunakan metodologi Accelarated Learning (lozanov) dengan prinsip suggestology dan Neuro Linguistic Programming. percepatan belajar (Accelerated Learning) juga dikembangkan untuk menyingkirkan hambatan belajar yang menghalangi proses alamiah dengan disengaja menggunakan musik, mewarnai lingkungan sekeliling, menyusun bahan pembelajaran yang sesuai, cara efektif penyajian, modalitas belajar serta keterlibatan yang aktif dari peserta didik. Dengan demikian berarti pemercepatan belajar yaitu kecepatan belajar yang memungkinkan peserta didik dengan kecepatan yang mengesankan, dengan upaya yang normal, dan dibarengi kegembiraan tercapai.

Kompetensi dasar akar pangkat tiga suatu bilangan kubik merupakan kompetensi dasar yang menjadi objek penelitian, karena hasil evaluasi belajar pada kompetensi dasar ini masih belum mencapai ketuntasan belajar $(<75)$. Penulis juga menganggap penting penguasaan Kompetensi Dasar akar pangkat tiga suatu bilangan kubik karena merupakan materi yang baru yang nantinya sangat penting sebagai prasyarat untuk sampai pada materi volume dan debit. 
Berdasarkan hal-hal yang telah dikemukakan selanjutnya menarik untuk dikaji. Seberapa besar keaktifan belajar peserta didik kelas VI SD Negeri 02 Sidomulyo dalam pelajaran matematika untuk kompetensi dasar "akar pangkat tiga suatu bilangan kubik" menggunakan kartu domino bilangan kubik - akar pangkat tiga.

Bagaimanakah perubahan perilaku keaktifan peserta didik kelas VI SD Negeri 02 Sidomulyo, Kec. Lebakbarang, Kab. Pekalongan pada kompetensi dasar akar pangkat tiga suatu bilangan kubik setelah mendapat perlakuan pembelajaran dengan pendekatan konstekstual berorientasi Quantum Math Learning menggunakan teknik bermain kartu domino bilangan kubik-akar pangkat tiga?

Berdasarkan masalah yang diteliti, penelitian ini bertujuan: Menentukan besaran peningkatan hasil belajar dan keaktifan belajar peserta didik kelas VI SD Negeri 02 Sidomulyo, Kec. Lebakbarang, Kab. Pekalongan pada kompetensi dasar akar pangkat tiga suatu bilangan kubik yang telah mendapat perlakuan pendekatan konstektual learning berorientasi Quantum Math Learning dengan teknik bermain.

Memaparkan perubahan perilaku belajar peserta didik kelas VI SD Negeri Sidomulyo 02 pada kompetensi dasar akar pangkat tiga suatu bilangan kubik setelah mendapat perlakuan pembelajaran dengan pendekatan kontekstual berorientasi Quantum Math Learning dengan teknik bermain kartu domino bilangan kubik-akar pangkat tiga.

Hasil penelitian ini diharapkan dapat bermanfaat bagi peserta didik, senang dalam belajar, menumbuhkan rasa percaya diri, memberikan motivasi belajar, meningkatkan kemampuan daya ingat (memori) dan logika serta diharapkan dapat meningkatkan hasil belajar. Bagi sekolah pendidik-pendidik lain termotivasi untuk meningkatkan diri dalam melakukan peningkatan diri dalam melakukan kegiatan pembelajaran matematika (lebih kreatif, produktif, dan inovatif dengan membuat alat peraga/ alat bantu pembelajaran), sehingga pembelajaran menjadi efektif, 
goalnya sekolah mampu menghasilkan lulusan (out-put) yang berkualitas. Bagi komite sekolah, lebih mendukung program sekolah yang berkaitan dengan peningkatan sumber daya manusia (SDM) yang sangat menentukan pada peningkatan hasil belajar peserta didik.

\section{LANDASAN TEORI}

\section{Teori belajar dan belajar Matematika}

Menurut Gagne (dalam Tasfirani 2008: 17), belajar merupakan suatu proses dimana suatu organisme berubah perilakunya akibat suatu pengalaman. Galloway (dalam tasfirani 2008: 17) mengatakan belajar merupakan suatu proses internal yang mencakup ingatan, retensi, pengolahan informasi, emosi dan factor-faktor lain berdasarkan pengalaman-pengalaman sebelumnya.

Menurut Hudoyo (2003), seseorang dikatakan belajar bila diasumsikan bahwa di dalam diri orang tersebut terjadi perubahan tingkah laku. Tidak semua tingkah laku yang terjadi pada diri seseorang terjadi karena proses belajar. Perubahan yang terjadi karena proses belajar memiliki ciri-ciri tertentu. Ciri-ciri perubahan tingkah laku dalam belajar adalah:

a) Perubahan itu terjadi karena sadar,

b) Perubahan yang terjadi bersifat kontinyu dan fungsional,

c) Perubahan itu bersifat positif dan aktif,

d) Perubahan itu bukan bersifat sementara, dan

e) Perubahan itu mencakup keseluruhan aspek tingkah laku.

Ciri pokok belajar adalah sebagai perubahan prilaku yang relatif sebagai hasil dari pengalaman.

Belajar matematika merupakan kegiatan mental yang tinggi, karena matematika berkatan dengan ide-ide abstrak yang diberi simbol-simbol yang tersusun secara hierarkhis dan penalarannya deduktif. Matematika mengkaji objek abstrak (benda pikiran) yang disusun dalam 
suatu sistem aksiomatik dengan menggunakan simbol (lambang) dan penalaran (deduktif). Dan sistem matematika merupakan jaringan yang rumit yang terdiri dari :

a) Pengertian/konsep pangkal (undefined term, primitive concept) yaitu pengertian yang tidak perlu dijelaskan.

b) Definisi (defined term) yaitu pengertian yang perlu dijelaskan.

c) Pengertian pangkal (aksioma postulat) adalah suatu pernyataan yang biasanya kebenarannya tidak perlu pembuktian. Pemilihan suatu pernyataan menjadi aksioma dipilih dari pernyataan-pernyataan yang mudah diterima.

d) Teorema/dalil adalah pernyataan yang kebenarannya perlu dibuktikan. Teorema diturunkan secara logis dari sejumlah pengertian pangkal, definisi dan aksioma. Teorema merupakan hasil penarikan dari kesimpulan secara deduktif dari sejumlah konsep pangkal, definisi dan aksioma. Penarikan kesimpulan secara deduktif dengan penalaran logis yang terbentuk “ jika ................ maka ..............."

Dalam sistem matematika yang demikian kiranya sulit bagi peserta didik SD untuk memahaminya. Tetapi matematika yang terdapat dalam kurikulum SD adalah matematika yang telah dipilih dan disederhanakan serta disesuaikan dengan tingkat perkembangan berpikir peserta didik SD.

Untuk mempelajari matematika haruslah bertahap, berurutan serta mendasarkan pengalaman belajar yang lalu (sebelumnya). Proses belajar matematika akan terjadi dengan lancer bila dilakukan secra rutin dan berkelanjutan. Menurut Sukahar (1992: 3) belajar matematika pada hakekatnya adalah belajar yang berkaitan dengan ide-ide, struktur-struktur yang 
diatur menurut urutan logis. Belajar matemtika tidak akan berarti bila hanya dihafalkan saja. Belajar matematika akan bermakna bila dimengerti.

\section{Pendekatan Pembelajaran Matematika}

Pendekatan pembelajaran adalah suatu jalan, cara atau kebijakan yang ditempuh pendidik atau peserta didik dalam pencapaian tujuan pembelajaran dilihat dari sudut bagaimana proses atau materi pembeljaran itu, umum atau khusus dikelola (Rus effendi dalam Fauzi 2002: 13).

Soejadi (1999: 102), mengklasifikasikan pendekatan pembelajaran matematika menjadi dua, yaitu:

1) Pendekatan materi (material approach), yaitu proses pembelajaran topik matematika tertentu menggunakan materi matematika lain.

2) Pendekatan pembelajaran (teaching approach), yaitu proses penyampaian suatu penyajian topik matematika tertentu agar mempermudah peserta didik memahaminya.

Jerome Bruner menyatakan dalam teorinya bahwa belajar matematika akan lebih berhasil jika proses pengajaran diarahkan kepada konsep-konsep dan struktur-struktur yang terbuat dalam pokok bahasan yang diajarkan, disamping hubungan yang terkait dengan konsep-konsep dan struktur-struktur (Suherman, 2003: 43).

Bruner melalui teorinya mengungkapkan bahwa dalam proses belajar anak sebaiknya diberi kesempatan untuk memanipulasi benda-benda (alat peraga). Melalui alat peraga yang ditelitinya itu, anak akan melihat langsung bagaimana keteraturan dan pola struktur yang terdapat dalam benda yang sedang diperhatikannya itu. Keteraturn itu kemudian oleh anak dihubungkan dengan keterangan intuitif yang telah melekat pada dirinya.

Metode yang sangat didukung oleh Bruner adalah metode belajar dengan penemuan. Ia meyakini bahwa dalam mempelajari matematika anak perlu secara langsung menggunakan 
bahan-bahan manipulatif. Bahan -bahan tersebut merupakan benda kongkret yang dirancang khusus dan dapat diutak-atik oleh peserta didik dalam berusaha untuk memahami suatu konsep matematika. Adanya interaksi peserta didik dengan lingkungan fisik ini akan memberikan kesempatan bagi dirinya untuk melaksanakan penemuan. Dalam kaitannya dengan pengalaman fisik ini, Bruner mengemukakan tiga tahap sajian benda, yaitu :

Tahap enactive (kongkret).Peserta didik belajar dengan memanipulasi benda-benda (objek) kongkret secara langsung.

Tahap econic (semi kongkret).Peserta didik memahami konsep matematika yang bersifat abstrak itu dengan bantuan model-model semi kongkret berupa; gambar atau grafik, tabel, bagan, peta dan sebagainya.

Tahap simbolic (abstrak).Peserta didik belajar konsep dan operasi matematika langsung dengan kata-kata atau simbol-simbol tanpa bantuan objek kongkret atau semi kongkret.

Treffers (dalam Nurhadi, 2003), mengklasifikasikan pendekatan matematika berdasarkan pada penekanan penggunaan komponen proses matematisasinya, yakni matematisasi horisontal dan matematisasi vertikal, ke dalam empat macam pendekatan, yaitu: mekanistik, strukturalistik, emperistik, dan realistik.

Menurut Yuwono (2001 : 4) dalam proses matematisasi horisontal, dengan pengetahuan atau pengalaman yang dimilikinya, peserta didik dapat mengorganisasikan dan memecahkan masalah nyata dalam kehidupan sehari-hari. Dengan kata lain proses matematisasi horisontal bergerak dari nyata ke dunia simbol. Proses ini meliputi proses informal yang dilakukan peserta didik dalam menyelesaikan suatu soal. Contohnya adalah suatu proses yang dilalui peserta didik untuk membuat model, membuat skema dan menemukan hubungan-hubungan. Sedangkan proses mtematisasi vertikal, merupakan proses pengorganisasian kembali dengan menggunakan matematika. Ini berarti proses matematisasi vertikal bergerak dari dunia symbol ke dunia nyata. 
Proses ini antara lain meliputi: proses menyatakan suatu hubungan dengan suatu formula (rumus), membuat berbagai model, merumuskan konsep/prinsip dan melakukan generalisasi.

Menurut Yuwono (2001: 4) berdasarkan uraian diatas, perbedaan dari pendekatan pembelajaran maematika berdasarkan intensitas pematematikaannya dapat dijelaskan sebagai berikut.

1) Pendekatan mekanistik, lebih memusatkan pada tubian (drill) dan hafalan, sedangkan proses pematematikaannya tidak nampak.

2) Pendekatan strukturalistik, lebih menekankan pada pematematikaan vertikal dan cenderung pematematikaan horisontal.

3) Pendekatan emperistik, lebih menekankan pada pematematikaan horisontal dan mengabaikan pematematikaan vertikal.

4) Pendekatan realistik, memberikan perhatian yang seimbang antara pematematikaan horisontal dan pematematikaan vertikal dengan penyampaian secara terpadu.

Berdasarkan berbagai pendapat dan uraian di atas, dalam penelitian ini akan digunakan pembelajaran matematika yang berpandu pada pendekatan realistik.

\section{Pendekatan Pembelajaran Kontekstual}

Pendekatan kontekstual adalah salah satu pendekatan matematika yang mengajarkan kepada peserta didik dengan mempreentasikan masalah dan meng'encourage' atau mendorong peserta didik untuk menemukan cara mereka sendiri dalam menyelesaikan permasalahan. Para peserta didik diperdayakan oleh pengetahuannya yang berada dalam diri mereka melalui serangkaian pertanyaan produktif (Suherman $2003: 75$ ). 
Pembelajaran kontekstual (contextual teaching and learning) adalah pembelajaran yang dimulai dengan mengambil (mensimulasikan, menceritakan) kejadian pada dunia nyata kehidupan seharihari yang dialami peserta didik kemudian diangkat ke dalam konsep matematika yang sedang dibahas melalui proses tanya jawab dalam bentuk diskusi. Pembelajaran kontekstual melibatkan tujuh komponen utama pembelajaran, yaitu konstruktivisme (constructivism), bertanya (questioning), menemukan (inquiry), masyarakat belajar (learning community), pemodelan (modeling), refleksi (reflection) dan penilaian yang sebenarnya (authentic assessment).

Menurut Sudrajat (2007 : 3) ada tujuh prinsip pembelajaran Kontekstual, yaitu sebagai berikut:

1) Konstruktivisme (constructivism)

Dalam pandangan ini strategi yang dieroleh lebih diutamakan dibandingkan seberapa banyak peserta didik memperoleh dan mengingat pengetahuan, karena itu tugas pendidik adalah memfasilitasi proses tersebut dengan cara:

a) Menjadikan pengetahuan bermakna dan relevan bagi peserta didik,

b) Memberi kesempatan bagi peserta didik untuk menemukan dan menerapkan idenya sendiri, dan

c) Menyadarkan peserta didik agar menerapkan strategi mereka sendiri dalam belajar

2) Menemukan (inquiry)

Dalam pengertian menemukan sebagai inquiry, prinsip ini mempunyai seperangkat siklus,yaitu observasi, bertanya, mengajukan dugaan, mengumpulkan data, dan menyimpulkan. Sebagai pendekatan pembelajaran matematika. Misalnya, menanamkan konsep pangkat sebagai bentuk perkalian berulang.

3) Bertanya (questioning)

Kegiatan bertanya merupakan salah satu kegiatan dalam mengawali, menguatkan, dan menyimpulkan sebuah konsep. Bentuknya dapat dilakukan pendidik langsung kepada peserta 
didik atau justru memancing peserta didik untuk bertanya kepada pendidik, kepada peserta didik lain atau kepada orang lain secara khusus (nara sumber). Kegiatan ini sangat menunjang setiap aktivitas belajar, karena pengetahuan yang dimiliki seseorang biasanya berawal dari "bertanya" (questioning).

Bertanya dalam pembelajaran dipandang sebagai kegiatan pendidik untuk mendorong, membimbing dan menilai kemampuan berpikir peserta didik. Selain itu bertanya juga dapat digunakan untuk menggali informasi, menginformasikan apa yang sudah diketahui dan mengarahkan perhatian pada aspek yang belum diketahui, kebenaran tentang pentingnya pertanyaan yang baik (good questions) dikuatkan oleh Orton, (1991) menyatakan bahwa "good question are important in facilitating learning"

Bertanya dalam pembelajaran konstektual merupakan kegiatan yang sangat penting dilakukan pendidik untuk mengantarkan peserta didik membangun pengetahuan sendiri. Menurut Turmudi (2007), serangkaian pertanyaan pendidik dikatakan produktif apabila :
a) Menggali informasi akademis,
b) Mengecek pemahaman peserta didik,
c) Membangkitkan respon kepada peserta didik,
d) Mengetahui hal-hal yang sudah diketahui peserta didik,
e) Memfokuskan perhatian peserta didik pada sesuatu yang sudah diketahui peserta didik,
f) Membangkitkan lagi lebih banyak pertanyaan dari peserta didik, dan
g) Menyegarkan kembali pengetahuan peserta didik.

4) Masyarakat belajar (learning community)

Konsep masyarakat belajar (learning community) menyarankan agar hasil pembelajaran diperoleh dari kerjasama dengan orang lain. Masyarakat belajar biasa terjadi apabila ada komunikasi dua arah, yaitu pendidik terhadap peserta didik atau sebaliknya, dan 
peserta didik dengan peserta didik lainnya dalam bentuk sharing. Sudrajat (2007) berkesempatan melakukan penelitian tentang komunikasi dalam ranah kemampuan membaca matematika. Hasilnya, seperti yang telah diduga sebelumnya bahwa ketidakoptimalan hasil belajar yang diharapkan dari pemberian perlakuan suatu teknik atau strategi yang baru berakar pada permasalahan yang klasik dan senantiasa menghantui pembelajaran matematika selama ini, yaitu pada masalah kurangnya penguasaan konsep dasar. Jadi pada dasarnya komunikasi dalam masyarakat beljar matematika dapat optimal bila komunikan dan komunikator memiliki penguasaan konsep dasar.

5) Pemodelan (modelling)

Pemodelan menurut pendekatan pembelajaran kontekstual, pendidik bukan merupakan satu-satunya model, melainkan harus memfasilitasi suatu model tentang "bagaimana cara belajar", baik dilakukan oleh peserta didik maupun oleh pendidik sendiri. Model juga biasa didatangkan dari luar. Seseorang yang mempunyai keahlian tertentu dapat dihadirkan ke dalam kelas untuk menjadi model terhadap suatu pembelajaran. Penggunaan alat peraga matematika dari suatu benda konkret bias menjadi model untuk menjelaskan konsep matematika yang abstrak.

6) Refleksi (Reflection)

Refleksi merupakan cara berpikir tentang apa yang baru dipelajari dan dilakukan setiap peserta belajar. Pendidik mengoreksi dirinya, peserya didik dikoreksi oleh pendidikrnya atau sebaliknya. Nilai fundamental dari prinsip ini adalah semangat introspeksi untuk perbaikan pada kegiatan pembelajaran berikutnya.

7) Penilaian yang sebenarnya (Authentic Assessment)

Hakekat penilaian sebenarnya adalah bahwa kemajuan belajar dinilai dari proses bukan melalui hasil, dan dengan berbagai cara tes hanyalah salah satunya. Penilaian sebenarnya 
menilai pengetahuan dan keterampilan yang diperoleh peserta didik. Penilai tidak hanya pendidik tetapi bias juga teman atau orang lain. Karakteristik penilaian sebenarnya adalah:

a) Dilaksanakan selama dan sesudah pembelajaran berlangsung,

b) Bisa digunakan untuk sumatif maupun formatif,

c) Yang diukur keterampilan dan performasi, bukan mengingat fakta,

d) Berkesinambungan,

e) Terintegrasi, dan

f) Dapat digunakan sebagai feed back (umpan balik).

Silberman (2004: 6) menyatakan makin banyak keaktifan beljar yang dilakukan oleh pesert didik makin banyak pengetahuan dan keterampilan yang akan diperoleh. Penguasaan pengetahuan dan keterampilan siswa berpengaruh terhadap nilai hasil belajarnya. Sebagaimana yang telah confusius ungkapkan pada ratusan tahun sebelumnya:

What I hear, I forget

What I hear and see, I remember a little

What I hear, see and ask questions about or discuss with someone else, I begin to understand What I hear, see, discuss and do. I acquire knowledge and skill

What I teach to another, I master. (Silberman 2004: 2)

\section{Teknik bermain dalam model Quantum Math Learning}

Teknik bermain dalam model quantum math learning adalah sebuah pendekatan belajar matematika model quantum yang mempromosikan citra matematika sebagai ilmu yang menyenangkan, mudah, dan menantang untuk dipelajari. Quantum math learning memberikan solusi terhadap masalah pembelajaran konsep dasar matematika dengan menggunakan metode sederhana, mudah dan menyenangkan, cepat, akurat, efektif, efisien, meringankan kerja otak, meningkatkan kreatifitas dan daya piker anak, dengan tetap memperhatikan aspek psikologi perkembangan dan psikologi pembelajaran (Matrisoni $2008: 1$ ). 
De Porter (1992) mengartikan Quantum sebagai interaksi yang mengubah (mengorkestrasi) energi menjadi cahaya. Interaksi mencakup unsure-unsur untuk belajar efektif yang mempengaruhi kesuksesan belajar. Interaksi ini mengubah kemampuan dan bakat alamiah peserta didik, yang diharapkan bermanfaat bagi mereka sendiri dan bagi orang lain. Masih menurut De Porter (dalam Saryono, 2008), istilah mengubah dan mengorkestrasi di adopsi dari dunia musik, untuk mengubah dan memadukan suasana pembelajaran secara harmonis langkah-langkahnya sebagai berikut:

1) Mengorkestra suasana belajar menjadi suasana yang amat menyenangkan bagi peserta didik. Hal tersebut berarti pendidik bersikap ramah, antusias, hangat, dan menarik.

2) Membuat agar segalanya "berbicara" tentang materi yang kita ajarkan,

3) Membuat agar segalanya bertujuan untuk keberhasilan belajar peserta didik,

4) Memberikan pengalaman awal (peserta didik mengkontruksi sendiri pengetahuannya), selanjutnya pendidik memberikan arahan yang diperlukan,

5) Memberi pengakuan pada setiap usaha yang telah dilakukan oleh peserta didik, yaitu dengan memberikan reward (penghargaan) berupa ucapan : bagus, hebat, jempol, tingkatkan terus, dan sebagainya atau dengan memberikan hadiah berupa bintang emas untuk peringkat I, perak untuk peringkat II, perunggu peringkat III atau bisa juga peringkat I mendapat 3 nilai, peringkat II mendapat 2 nilai, sedangkan peringkat III hanya 1 nilai. Setiap 3 bintang perunggu dapat ditukar 1 bintang emas dan setiap 3 bintang perak dapat ditukarkan dengan 2 bintang emas.

6) Jika suatu materi layak dipelajari, keberhasilannya layak pula dirayakan. Artinya rayakanlah keberhasilan dari setiap peserta didik,

7) Mengatur suasana dan lingkungan yang kondusif untuk belajar, dan 
8) Menciptakan keriangan dan ketakjuban dengan suara musik yang lembut, tetapi tidak mengganggu peserta didik dalam belajarnya.

Menurut De porter (dalam Saryono, 2008) strategi lain yang dapat ditempuh dalam pembelajaran berorientasi QML adalah sebagai berikut :

a. Menumbuhkan motivasi belajar, misalnya melalui AMBAK (apa manfaatnya bagiku),

b. Menumbuhkan rasa percaya diri,

c. Menghilangkan penyebab gangguan belajar, menciptakan suasana yang nyaman dan santai,

d. Meyakinkan bahwa keahlian memerlukan latihan dan pengulangan,

e. Mengenali gaya belajar yang amat disukai peserta didik (dengan visual/melihat, auditorial/mendengar, ataukah dengan kinestetik/bekerja,

f. Manfaatkan setiap waktu tanpa tekanan,

g. Ketika akhirnya tercapai tujuannya, rayakanlah

h. Menggunakan musik yang lembut, yang disukai peserta didik.

Menurut Sudrajat (2008 : 1) dengan quantum learning suasana pembelajaran efektif dapat diciptakan melalui campuran antara lain unsure-unsur hiburan, permainan, cara berpikir positif, dan emosi yang sehat. Prinsipnya adalah bahwa sugesti dapat dan pasti mempengaruhi hasil situasi belajar. Sugesti yang positif dapat dilakukan melalui beberapa teknik, diantaranya para peserta didik di dalam kelas di dalam kelas dibuat menjadi nyaman, memasang musik latar di belakang kelas, dan meningkatkan partisipasi individu. Dengan demikian pemercepatan belajar, yakni proses belajar yang memungkinkan peserta didik belajar dengan kecepatan yang mengesankan, dengan upaya yang normal, dan dibarengi kegembiraan tercapai. 


\section{Kartu bilangan kubik-akar pangkat tiga}

Kartu bilangan kubik-akar pangkat tiga adalah alat peraga berupa kartu bilangan yang di desain seperti kartu domino.Pada satu ujung tertulis bilangan kubik dan pada ujung yang satunya tertulis akar pangkat tiga. (casto nuredi )

Kartu ini di desain seperti gambar di bawah ini :

Contoh kartu

\begin{tabular}{|c|c|c|c|c|}
\hline \begin{tabular}{|c|}
$9^{3}$ \\
\end{tabular} & $8^{3}$ & $7^{3}$ & $6^{3}$ & $5^{3}$ \\
\hline 1 & 64 & 125 & 729 & 303 \\
\hline
\end{tabular}

Gbr 1. Model kartu bilangan kubik-akar pangkat tiga

Kartu ini satu set seluruhnya berjumlah 81 kartu.

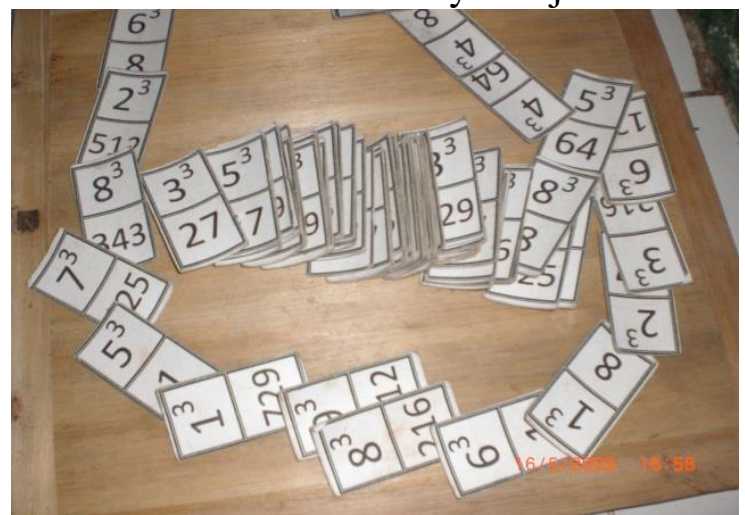

Gbr. 2 Kartu bilangan kubik-akar pangkat tiga

Kartu bilangan kubik-akar pangkat tiga tersaji lengkap dalam pembelajaran setelah peserta didik melakoni sebuah permainan. Peserta didik mengurutkan kartu sehingga ujung yang satu terpasang cocok (bilangan kubik dengan akar pangkat tiganya) sehingga seluruh kartu (81 kartu) terpasang habis.

Cara bermain kartu ini adalah seperti permainan domino yaitu mencocokkan pasangan bilangan kubik dengan akar pangkat tiganya. 
1. Pada awal permainan kartu dikocok, jika pemain terdiri dari 3 orang masing-masing pemain mendapat 9 kartu, bila pemain terdiri dari 6 orang masing-masing pemain mendapat 7 kartu. Sisa kartu yang dibagi ditumpuk diletakkan ditengah-tengah arena permainan.

2. Untuk mengawali permainan, salah seorang pemain memilih salah sebuah kartu secara acak diletakkan dibuka ditengah-tengah arena. Kemudian pemain yang lain melanjutkan kartu berikutnya yang sesuai.

3. Kartu yang dijatuhkan pemain berikutnya harus sesuai dengan salah satu ujung kartu yang sudah terbuka ditengah-tengah arena apabila belum ada kartu yang sesuai maka pemain yang sedang giliran main mengambil kartu yang masih berada pada tumpukan di tengahtengah arena. Bila tumpukan ditengah arena sudah habis belum ada yang sesuai maka giliran pemain tersebut terbakar, menjadi giliran pemain berikutnya.

4. Pemain yang kartunya habis pertama kali adalah pemain yang menang, permainan dilanjutkan terus sampai selesai tinggal seorang pemain yang dinyatakan kalah.

5. Pemain yang kalah mendapat hukuman sesuai dengan kesepakatan bersama pemain yang menang.

\section{METODE PENELITIAN}

Penelitian ini adalah penelitian tindakan kelas yang digunakan untuk memperbaiki pola pembelajaran matematika. Penelitian ini dilaksanakan dengan kolaborasi bersama dengan rekan pendidik kelas yang lain untuk mengamati interaksi dalam proses pembelajaran berdasarkan pola rancangan yang telah dirumuskan bersama.

Peserta didik kelas VISD negeri 02 Sidomulyo, Kec. Lebakbarang, Kab. Pekalongan Tahun Pelajaran 2009/2010. 
Variable yang diteliti dan dikembangkan dalam penelitian ini yaitu: keaktifan peserta didik selama proses pembelajaran, keterampilan proses, dan hasil belajar peserta didik.

\section{Prosedur penelitian}

Penelitian dilaksanakan dalam dua siklus dimana siklus kedua merupakan penyempurnaan tindakan dari hasil siklus sebelumnya. Masing-masing siklus memiliki tahapan sebagai berikut:

Gbr. 3 Siklus penelitian

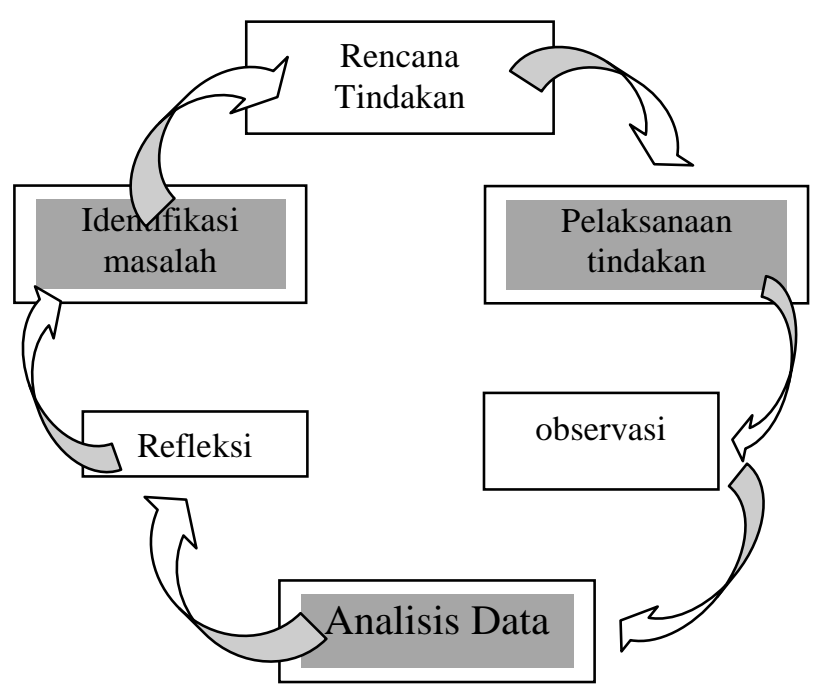

Proses tindakan siklus I

Perencanaan

Instrumen yang dipersiapkan untuk perencanaan meliputi: silabus, sistem penilaian, Rencana Pelaksanaan Pembelajaran (RPP) dan instrument penelitian.

Pelaksanaan tindakan

Pada tahap awal peserta didik diberi penjelasan tentang tugas dan aturan permainan, peserta didik dibagi menjadi dua kelompok, kemudian diberi kesempatan untuk diskusi untuk melaksanakan permainan. Permainan dimulai dengan terlebih dahulu dilakukan pembagian tugas agar permaina berjalan lancer, salah seorang bertinadak sebagai pemain sekaligus pengatur permainan 
Pada kegiatan inti peserta didik bertukar pendapat dalam kelompoknya dan mulai menyusun konsep bilangan kubik dan akar pangkat tiga suatu bilangan kubik. Pendidik membagi kartu tugas.

Observasi

Observasi dilakukan bersama dengan pelaksanaan tindakan, peneliti/pendidik menilai kecermatan dan aktivitas peserta didik dalam permainan dan diskusi kelompok dengan membuat catatan lapangan (field notes) untuk digunakan pada saat refleksi.

Refleksi

Pada akhir siklus diadakan refleksi dengan cara pemberian tes tertulis pada peserta didik. Hasil tes dan observasi aktivitas peserta didik dijadikan dasar perubhan dan perbaikan tindakan pada siklus II. Kekurangan yang muncul diupayakan untuk diperbaiki dan hal-hal yang positif dipertahankan dan ditingkatkan pada siklus II

Prose tindakan siklus II

Perencanaan

Instrumen yang dipersiapkan untuk perencanaan meliputi: silabus, sistem penilaian, Rencana Pelaksanaan Pembelajaran (RPP) dan instrument penelitian.

Pelaksanaan tindakan

Pada tahap awal peserta didik diberi penjelasan tentang tugas dan aturan permainan, peserta didik dibagi menjadi dua kelompok, kemudian diberi kesempatan untuk diskusi untuk melaksanakan permainan. Permainan dimulai dengan terlebih dahulu dilakukan pembagian tugas agar permainan berjalan lancar, salah seorang bertinadak sebagai pemain sekaligus pengatur permainan

Pada kegiatan inti peserta didik bertukar pendapat dalam kelompoknya dan mulai menyusun konsep bilangan kubik dan akar pangkat tiga suatu bilangan kubik. Kemudian 
pendidik membagikan kartu tugas setelah terlebih dulu memberikan evaluasi terhadap pelaksanaan siklus I.

Observasi

Observasi dilakukan bersama dengan pelaksanaan tindakan, peneliti/pendidik menilai kecermatan dan aktifitas peserta didik dalam permainan dan diskusi kelompok dengan membuat catatan lapangan (field notes) untuk digunakan pada saat refleksi.

Refleksi

Pada akhir siklus diadakan refleksi dan diakhiri dengan tes tertulis pada peserta didik. Hasil tes dan observasi dijadikan sebagai dasar pengolahan data dan pembuktian apakah terbukti bahwa penerapan permaianan domina kartu bilangan kubik/akar pangkat tiga sebagai Quantum Math Learning dapat meningkatkan prestasi dan keaktifan peserta didik dalam pembelajaran matematika.

\section{Tehnik dan alat pengumpulan data}

Tehnik

Tehnik tes

Tehnik tes dilakukan dengan mengadakan pretes pada kondisi pra-siklus, serta postes pada akhir siklus I dan akhir siklus II.

Pretes/sebelum tindakan.

Pre-tes dilakukan sebelum dilaksanakannya tindakan kelas diselenggarakan secra tertulis dengan jenis soal pilihan ganda 20 soal dan isian 10 soal.Waktu yang diberikan 15 menit.

\section{Siklus I}

Post-tes akhir siklus I dilaksanakan setelah peserta didik melakukan serangkaian kegiatan tindakan mulai dari perencanaan, pelaksanaan tindakan, observasi dan refleksi. Bentuk dan 
jumlah soal sama dengan pretes namun materi yang diteskan berbeda yaitu pada esensi kompetensi dasar "akar pangkat tiga suatu bilangan kubik". Waktu tes 15 menit.

Siklus II

Post-tes akhir siklus II dilaksanakan dengan tujuan untuk mngetahui sejauh mana perlakuan/tindakan memberikan dampak/efek terhadap kemajuan hasil belajar peserta didik. Dengan asumsi bahwa peserta didik akan dapat mengerjakan tes dengan bentuk soal yang bervariasi maka pada postes siklus II bentuk dan jumlah soal dibuat sama seperti pada siklus I namun dengan materi yang berbeda yaitu "bilangan kubik dan akar pangkat tiga suatu bilangan kubik".

Tehnik non-tes

Tehnik non-tes dilaksanakan dengan melakukan observasi/pengamatan terhadap kemajuan peserta didik, menganalisis hasil wawancara dengan pendidik dan peserta didik, analisis hasil quisioner dan sosiogram serta catatan anekdot.

\section{Lembar observasi}

Lembar observasi digunakan oleh peneliti dengan tujuan untuk memperoleh gambaran tentang minat dan aktivitas peserta didik dengan diberikannya tindakan kelas oleh pendidik diberikan kepada peserta didik. Sedangkan lembar observasi pendidik diisi oleh pendidik lain sebagai kolaborator dengan tujuan agar peneliti memperoleh gambaran tentang penguasaan dan ketepatan model pembelajaran yang diterapkan. Pada penelitian ini pendidik sekaligus sebagai peneliti sehingga membutuhkan seorang kolaborator agar data yang diperoleh lebih akurat dan dapat dipertanggungjawabkan kebenarannya.

\section{Pedoman wawancara}

Wawancara dilakukan oleh peneliti terhadap peserta didik dan pendidik untuk mengumpulkan data-data awal penelitian serta hasil dari pelksanaan tindakan di akhir penelitian. Pedoman wawancara disusun dengan meliht unsure manfaat dan kebutuhan akan data penelitian. Sosiometri dan sosiogram 
Digunakan untuk merekam sosialisasi antar peserta didik selama proses penelitian dan pemberian tindakan. Dengan sosiogram akan terekam relasi dan korelasi antar peserta didik dalam kelas.

Catatan

Hal-hal penting atau ganjil selama pemberian tindakan seperti adanya peserta didik yang sakit, mengantuk ketika pendidik member penjelasan, ketidakaktifan peserta didik ketika proses diskusi merupakan catatan penting yang harus terekam pendidik. Untuk memuat hal-hal seperti itu dibuat catatan anekdot.

Alat pengumpulan data

Alat pengumpulan data untuk tehnik tes menggunakan hasil nilai pre-tes, pos-tes siklus I dan siklus II. Untuk nontes menggunakan lembara observasi, daftara wawancara, kartu sosiometri dan catatan anekdot

Validasi dan analisis data

Sebuah tes dikatakan memiliki validitas apabila dapat mengukur apa yang seharusnya diukur. Berdasarkan validitas konten tes dapat dikatakan valid jika sesuai dengan kisi-kisi yang dibuat. Kisi-kisi disusun berdasarkan indicator Dalam Rencana Pelaksanaan Pembelajaran (RPP). Analisis data dilakukan dengan tehnik kuantitatif dan tehnik kualitatif Tehnik kuantitatif

Analisis data pada penelitian ini menggunakan analisis deskriptif komparatif (constant comparative method), dengn cara membandingkan hasil tes pada kondisi awal, hasil tes setelah siklus I dan hasil tes setelah siklus II

Tehnik kualitatif

Tehnik kualitatif dilakukan dengan membandingkan kemajuan yang diperoleh peserta didik melalui perubahan perilaku yang Nampak pada kondisi awal sebelum tindakan dan kondisi 
setelah diberlakukannya tindakan kelas pada siklus I dan siklus II. Hasil perbandingan kemudian dianalisis dan ditarik kesimpulan tentang hasil dari perlakuan tindakan kelas.

\section{HASIL PENELITIAN DAN PEMBAHASAN}

\section{Hasil Penelitian}

\section{Hasil tes}

Hasil penelitian pra siklus, siklus I dan siklus II menunjukkan peningkatan seperti yang tampak pada tabel 1. Sebagai berikut:

Tabel 1. Rekapitulasi Frekuensi Hasil ulangan

\begin{tabular}{|r|l|c|c|c||}
\hline \multirow{2}{*}{ No } & \multicolumn{2}{|c|}{ Nama } & \multicolumn{3}{|c|}{ Nilai } \\
\cline { 3 - 5 } & & $\begin{array}{c}\text { Sebel } \\
\text { um }\end{array}$ & $\begin{array}{c}\text { Siklus } \\
\text { I }\end{array}$ & $\begin{array}{c}\text { Siklus } \\
\text { II }\end{array}$ \\
\hline 1 & Peserta didik A & 5,50 & 6,50 & 8,00 \\
\hline 2 & Peserta didikB & 7,50 & 8,50 & 10,00 \\
\hline 3 & Peserta didikC & 7,00 & 7,50 & 8,50 \\
\hline 4 & Peserta didikD & 5,00 & 8,00 & 9,00 \\
\hline 5 & Peserta didikE & 6,50 & 6,50 & 7,00 \\
\hline 6 & Peserta didikF & 6,50 & 8,50 & 9,00 \\
\hline 7 & Peserta didikG & 5,00 & 8,00 & 9,00 \\
\hline 8 & Peserta didikH & 8,00 & 10,00 & 10,00 \\
\hline 9 & Peserta didikI & 7,00 & 7,50 & 8,50 \\
\hline 10 & Peserta didikJ & 5,00 & 7,50 & 9,00 \\
\hline 11 & Peserta didikK & 5,50 & 8,00 & 8,50 \\
\hline 12 & Peserta didikL & 6,00 & 8,00 & 9,50 \\
\hline 13 & Peserta didikM & 7,00 & 7,50 & 8,50 \\
\hline 14 & Peserta didikN & 4,00 & 7,00 & 7,00 \\
\hline 15 & Peserta didikO & 6,00 & 7,00 & 8,50 \\
\hline 16 & Peserta didikP & 5,00 & 7,00 & 8,50 \\
\hline 17 & Peserta didikQ & 6,50 & 7,00 & 9,00 \\
\hline 18 & Peserta didikR & 6,50 & 8,00 & 8,50 \\
\hline 19 & Peserta didikS & 6,50 & 8,00 & 9,50 \\
\hline Jumlah & 116.5 & 146 & 164.5 \\
\hline Nilai & Tertinggi & 8,00 & 10,00 & 10,00 \\
\hline Nilai & Terendah & 4,00 & 6,50 & 7,00 \\
\hline Rata-rata & 6,13 & 7,68 & 8,66 \\
\hline
\end{tabular}


Berdasarkan uraian hasil tes pada tabel 1. Dapat disimpulkan bahwa nilai rata-rata peserta didik mengalami peningkatan pada kondisi sebelum tindakan yaitu 61,1 persen menjadi 76,8 persen pada siklus I dan 86,6 persen pada siklus II. Hal ini menunjukkan peningkatan yang cukup besar yaitu 15,8 persen pada siklus I dan 25,5 persen pada siklus II. Setelah perbaikan tindakan pada siklus II terjadi peningkatan dari siklus I sebesar 9,7 persen.

Sedangkan nilai tertinggi peserta didik mengalami peningkatan yaitu dari 8 menjadi 10 pada siklus I dan Siklus II.

\section{Hasil Nontes}

siklus I

\section{Hasil pengamatan sikap/minat, kerjasama dan tanggung jawab}

Hasil pengamatan terhadap minat, kerjasama daan tanggung jawab peserta didik dapat mengikuti pembelajaran pada siklus I dapat diketahui bahwa sebagian besar peserta didik mempunyai minat yang tinggi dan baik untuk mengikuti pembelajaran .peserta didik terlihat aktif, bersemangat, sungguh-sungguh dalam menentukan pasangan bilangan kubik dengan akar pangkat tiganya, sungguh-sungguh saat melaksanakan permainan domino dan bekerjasama dalam kelompok untuk menyelesaikan permaian. Kesungguhan peserta didik untuk menyelesaikan permainan sangat besar ini karena ada competitor yaitu kelompok yang lain.

\section{Hasil analisis angket dan wawancara}

Berdasarkan analisis angket dan wawancara dengan beberapa peserta didik, mereka cukup senang dan merasa tertntang untuk menyelesaikan permainan sebagai teknik pembelajaran bilangan kubik dan akar pangkat tiga. Peserta didik merasakan manfaat dari teknik permainan dalam pembelajaran. Namun demikian pada siklus I peserta didik masih merasa takut dan ragu- 
ragu untuk menyelesaikan permainan. Sebagian dari mereka masih malu-malu terlibat dalam permainan. Penyebab munculnya perasaan-perasaan tersebut antara lain :

Peserta didik belum terbiasa terlibat aktif dalam pembelajaran. Teknik bermain dalam pembelajaran merupakan hal yang baru bagi peserta didik.

\section{Hasil refleksi}

Hasil refleksi dengan peserta didik dan kolaboran pada siklus I diperoleh data :

Perlu menambah waktu untuk peserta didik memahami peraturan permainan.

Perlu penjelasan ulang dan penegasan tentang cara bermain kartu domino bilangan kubik-akar pangkat tiga.

kriteria penilaian perlu diperjelas.

Perlu diberikan penghargaan dan hukuman dalam permainan.

Hasil refleksi pada siklus I sebagai bahan perbaikan pelaksanaan pembelajaran pada siklus II.

\section{Siklus II}

\section{Hasil pengamatan sikap/minat, kerjasama dan tanggung jawab}

Hasil pengamatan terhadap minat, kerjasama dan tanggung jawab peserta didik saat mengikuti pembelajaran pada siklus II dapat diketahui bahwa tidak ada peserta didik yang mempunyai minat cukup apalagi kurang dalam pembelajaran. Begitupun untuk kemampuan kerjasama dan tanggung jawab. Pada siklus ini selama pembelajaran peserta didik terlihat lebih aktif, lebih bersemangat, lebih sungguh-sungguh salam menjalankan permainan. Kesungguhan peserta didik dalam melaksanakan permainan dan kerjasama dalam kelompok ternyata membawa dampak pada peningkatan kemampuan peserta didik dalam menyelesaikan tugas untuk menyelesaikan operasi matematika yang melibatkan bilangan kubik dan akar pangkat tiga. Pada siklus II tidak terlihat lagi ada peserta didik yang canggung dan ragu-ragu untuk terlibat dalam 
permainan. Setiap peserta didik terlihat lebih siap dan lebih percaya diri dalam melaksanakan permainan.

\section{Hasil analisis angket dan wawancara}

Hasil analisis angket pada siklus ini diperoleh data bahwa semua peserta didik mempersiapkan diri lebih sungguh-sungguh, peserta didik merasa lebih nyaman, lebih percaya diri dan lebih rileks.

Berdasar angket pula diketahui bahwa sebanyak 19 peserta didik merasa senang karena bermain kartu domino bilangan kubik-akar pangkat tiga menambah keterampilan matematika, melatih peserta didik untuk berani tampil di depan, dan melatih peserta didik mengembangkan sikap analitis-kritis. Dua peserta didik merasa kurang senang karena harus lagi dibebani untuk menjadi pemimpin dalam kelompoknya untuk mengendalikan jalannya permainan sebagai ketua kelompok. Tetapi kedua peserta didik yang kurang senang tersebut karena tugasnya yang lebih dibandingkan dengan rekan-rekannya yang lain. Namun demikian diakhir siklus karena ada penghargaan dan hadiah maka kedua peserta didik tersebut malah menjadi lebih bangga karena dapat memimpin rekan-rekannya dalam bermain.

\section{Perubahan perilaku peserta didik sebelum tindakan dan sesudah tindakan}

a. Sebelum tindakan.

Antusiasme peserta didik dalam pembelajaran rendah, peserta didik bermain sendiri, bergurau dengan teman, cenderung pasif dan asyik dengan pikirannya sendiri. Peserta didik yang aktif mengikuti pembelajaran kurang dari $50 \%$.

b. Setelah tindakan

Antusiasme peserta didik meningkat, peserta didik yang bergurau berkurang, peserta didik mulai aktif tidak lagi asyik dengan pikirannya sendiri. Pada siklus II peserta didik lebih tertantang untuk mengikuti pembelajaran. Tuntutan untuk menjadi pemain terbaik 
menyebabkan peserta didika tidak ada yang mengandalkan temannya. Disamping itu peserta didik juga diberi tanggung jawab untuk menjadintim penilai sehingga peserta didik lebih bersemangat lagi. Hal ini sesuai betul dengan apa yang disampaikan oleh De porter (2008:23) yang menyatakan bahwa "orang agaknya dapat berkonsentrasi paling baik saat mereka lebih dituntut daripada biasanya, dan mereka dapat memberikan lebih dari biasanya”.

Hasil analisis angket dan wawncarapun menunjukkan hasil yang menggembirakan. Pada siklus II peserta didik sudah merasa lebih nyaman, rileks, percaya diri, dan bersemangat saat mengikuti permainan. Perasaan nyaman dan rileks ini dikarenakan peserta didik mempersiapkan diri dengan sungguh-sungguh dan sedikit terlatih untuk bermain kartu bilangan kubik-akar pangkat tiga. Hal ini sesuai dengan pendapat Morgan dalam Soekamto (1997:8) yang menyatakan bahwa "belajar merupakan proses perubahan di dalam kepribadian yang berupa kecakapan, sikap, kebiasaan dan kepandaian. Perubahan hasil belajar tersebut bersifat menetap dalam tingkah laku yang terjadi sebagai suatu hasil dari latihan atau pengalaman". Begitupun belajar matematika factor kemauan, latihan dan kebiasaan sangatlah menunjang.Oleh karena itu peserta didik harus selalu diltih dan dimotivasi untuk berani berbuat sehingga keterampilan matematikanya semakin meningkat.

Berdasarkan hasil analisis angket dan wawancara jug diketahui peserta didik merasakan manfaat pembelajaran akar pangkat tiga suatu bilangan kubik menggunakan teknik bermain model quantum math learning. Manfaat tersebut antara lain menambah keterampilan matematika dan melatih keberanian serta kerjasama dalam kelompok. Manfaat yang dirasakan peserta didik itulah yang menyebabkan peserta didik mengikuti pembelajaran dengan sungguh-sungguh. Berdasarkan data-data hasil penelitian tindakan kelas tersebut dapat disimpulkan bahwa pembelajaran matematika "akar pangkat tiga suatu bilangan kubik" dengan teknik bermain kartu domino bilangan kubik-akar pangkat tiga dapat meningkatkan motivasi dan hasil belajar peserta didik. 


\section{PEN U T U P}

\section{Simpulan}

Berdasar hasil penelitian dan pembahasan pada pelaksanaan penelitian tindakan kelas di kelas VI SD Negeri 02 Sidomulyo, Lebakbarang dapat disimpulkan sebagai berikut :

1. Melalui teknik bermain menggunakan kartu domino "bilangan kubik-akar pangkat tiga" hasil belajar peserta didik pada kompetensi dasar "akar pangkat tiga suatu bilangan kubik" dapat meningkat.

2. Keaktifan belajar peserta didik meningkat signifikan dari sebelum tindakan, dengan setelah tindakan.

3. Peserta didik lebih terampil pada tindakan siklus II dibandingkan dengan tindakan siklus I.

\section{Saran}

Berdasarkan hasil penelitian penulis menyarankan:

Teknik pembelajaran bermain kartu domino "bilangan kubik-akar pangkat tiga" dapat digunakan sebagai alternatif pembelajaran dengan pendekatan quantum math learning sebagai bentuk pembelajaran konstektual untuk meningkatkan hasil belajar matematika pada kompetensi dasar "akar pangkat tiga suatu bilangan kubik".

Dalam pembelajaran matematika diperlukan adanya variasi baik teknik, metode maupun alat peraga sehingga peserta didik menjadi tertarik, aktif, dan terampil dalam mengikuti pembelajaran.

Kepada rekan-rekan pendidik agar dalam proses pembelajaran tidak hanya melakukan pembelajaran secara konvensional tetapi dapat menggunakan berbagai model dan teknik serta alat peraga yang memadai " teknik bermain" dan alat peraga "kartu domino bilangan kubik-kar 
pangkat tiga" adalah salah satu alternative dalam pembelajaran kompetensi dasar "akar pangkat tiga suatu bilangan kubik". Dan alternatif yang lain rekan pendidik bisa berkreasi sebagai wujud pengembangan profesi. 


\section{DAFTAR PUSTAKA}

Anni, Catharina Tri. 2004. Psikologi Belajar. Semarang: UPT MKK Unnes.

Arikunto, Suharsimi. 2002. Dasar-Dasar Evaluasi Pendidikan (Edisi Revisi). Bandung: Bumi Aksara.

Arikunto, Suharsimi. 2008. Penelitian Tindakan Kelas. Bandung: Bumi Aksara.

De Porter, Bobbi, Mark Reardon dan Sarah Singer Nourie. 2004. Quantum Teaching. Mempraktekan Quantum Learning di ruang-ruang kelas. Bandung: Kaifa PT Mizan Pustaka.

BSNP. 2007. Standar Proses. Jakarta: BSNP.

Johson, Elaine B. 2007. Contextual teaching and Lerning.Menjadikan kegiatan Belajar Mengajar Mengasyikkan dan Bermakna.

Nizar, Achmad. 2009. Konstribusi Matematika dalam membangun daya nalar dan komunikasi peserta didik. Jurnal Pendidikan Inovatif. (diunduh, 5 september 2010)

Rahadi, Aristo. 2003. Model Pembelajaran. Jakarta: Depdiknas

Soekamto, Toeti. 1997. Teori Belajar dan Model-model Pembelajaran. Jakarta: Universitas Terbuka

Suherman, Erman. 2003. Strategi Pembelajaran Matematika Kontemporer. Bandung: Penerbit JICA-UPI. 


\section{Biodata:}

Nama

NIP

Jabatan

Unit Kerja

Alamat rumah

Nomor telepon

Email

Pendidikan
: Casto Nuredi, S.Pd.

: 197012191994081001

: Kepala Sekolah

: SDN 02 Sidomulyo, Kec. Lebakbarang

Kabupaten Pekalongan

: Jl. Pisma XIX Blok R.No.21 PGP Kedungwuni Timur, Kedungwuni, Pekalongan

: 081575896585 / 02854482230

: castonuredibapaknyahaqi@yahoo.co.id

: S2 Manajemen Pendidikan IKIP PGRI (sedang

menyelesaikan Tesis) 